\title{
QUALITATIVE PHYTOCHEMICAL SCREENING AND FTIR SPECTROSCOPIC ANALYSIS OF GREWIA TILIFOLIA (VAHL) LEAF EXTRACTS
}

\author{
DHARMASOTH RAMA DEVI*, GANGA RAO BATTU \\ A. U. College of Pharmaceutical Sciences, Andhra University, Visakhapatnam, A. P, India 530003 \\ Email: ramajoy90@gmail.com
}

Received: 15 Apr 2019, Revised and Accepted: 13 Jun 2019

\begin{abstract}
Objective: The present study aim is to analyse the phytochemicals present in Grewia tilifolia (Vahl) leaf extracts by using Qualitative phytochemical analysis, Fourier-transform infrared spectroscopy (FTIR).
\end{abstract}

Methods: The leaf extracts were prepared using eight different solvents. The phytochemical analysis Fourier transform infrared spectroscopy (FTIR) analysis were performed using standard methods.

Results: The FTIR spectroscopic studies revealed different characteristic peak values with various functional groups present in the compounds of respective extracts. The FT-IR analysis shows the presence of different functional groups such as alcohols, phenols, alkanes, carboxylic acids, aldehydes, ketones, alkenes, primary amines, aromatics, esters, ethers, alkyl halides and aliphatic amine compounds, which showed major compounds present in the leaf extracts. The present study generated the FTIR spectrum profile for the medicinally important plant Grewia tilifolia.

Conclusion: The present study provides evediences that different extracts of Grewia tilifolia leaf is useful to cure many serious diseases which remained still problematic and for further isolation of bioactive compounds from the plant which could be of interest for the development of the new drug.

Keywords: Grewia tiliaefolia (Vahl), Phytochemicals, Fourier-transform infrared spectroscopy (FTIR)

(C) 2019 The Authors. Published by Innovare Academic Sciences Pvt Ltd. This is an open access article under the CC BY license (http://creativecommons.org/licenses/by/4.0/) DOI: http://dx.doi.org/10.22159/ijcpr.2019v11i4.34936

\section{INTRODUCTION}

Plants are a very useful source of various bioactive compounds which have direct or indirect use in the treatment of various human ailments [1]. A large number of medicinal plants are used as an alternative medicine for diseases of man and other animals since most of them are without side effects when compared with synthetic drugs. These are not only used as medicines to maintain their health care, also consumed as food by several Tribes of the Indian subcontinent. Phytochemicals are responsible for medicinal activities of the plants [2].

Based on this fundamental knowledge several pharmaceutical industries are established. The phytochemical constituents that are playing a significant role in medicines can be identified using crude extracts/drugs of the plants [3]. In current year's research in medicinal plants growing rapidly due to high pharmacological activities. Spectroscopic methods are very rapid and cost-effective than other conventional methods.

Fourier-transform infrared spectroscopy (FTIR) is a high-resolution analytical technique to identify the bioactive compounds based on the functional group present in them and to reveal the structure of the compounds $[4,5]$. In Fourier-transform infrared spectroscopy (FTIR) molecules show absorption in a charecteristic range of frequency. The organic compounds mainly absorbed in the range of 4000-400 $\mathrm{cm}^{-1}$ which play a key role in the identification and charecterisation of the compounds which are present in the respective extracts [6].

Grewia tiliaefolia belongs to the family Tiliaceae and it is a mediumsized tree, up to $20 \mathrm{~m}$ in height, with a clear bole and grey to blackish brown rough fibrous bark peeling off in thin flakes; leaves simple, alternate [7]. The flowers are yellow, small on thick axillary peduncles and fruits are globose drupes of the size of a pea, 2-4 lobed, black when ripe, seeds 1-2 [8]. The bark is astringent, sweet, acrid, refrigerant, oleaginous, expectorant, antipruritic, vulnerary, constipating, emetic, styptic, aphrodisiac and tonic [9]. The bark of the G. tiliaefolia showed the presence of three tri-terpenoids, viz. Betulin, Friedelin and Lupeol. Roots showed the presence of
Friedelin and Lupeol [10]. Tri-terpenoids isolated from G. tiliaefolia bark at higher concentrations exhibited cytotoxic activity against LEUK-L1210 cells [11]. Stem bark of G. tiliaefolia showed the semen coagulant and cardiovascular effects [12]. It is useful in vitiated conditions of pitta and kapha, burning sensation, hyperdipsia, rhinopathy, ulcers, skin diseases, haematemesis and general debility. So, considering the clinical importance, the present study was designed to evaluate the standardised quality control of grewia tilifolia leaf [13].

\section{Plant description}

Large trees, bark dark brown or greyish-brown, rough, vertically striated; blaze brownish-red, fibrous, streaked; branchlets stellatetomentose. Leaves simple, alternate; stipules 7-10 $\mathrm{mm}$, lateral, auricled; petiole $8-35 \mathrm{~mm}$, stout, swollen tipped, pubescent; lamina 6-36 x 3-24 cm, broadly ovate or obliquely ovate to round, base obliquely cordate or subcordate, apex acute, margin double serrate or crenate-serrate, glabrescent above and hoary pubescent beneath, coriaceous, 5-7-ribbed from base, prominent, lateral nerves 3-6 pairs, pinnate, prominent, intercostae scalariform, prominent. Flowers bisexual, yellow, in axillary umbels; peduncle $1.5-2 \mathrm{~cm}$ long; sepals 5, pubescent; petals 5, yellow, half the length of sepals, entire or notched, densely tomentose outside; stamens many, free, inserted on a glandular torus; gland densely villous on the margin; ovary superior, globose, hirsute, 2-4-celled, ovules 2-many; style subulate; stigma obscurely lobed, recurved. Fruit a drupe, globose to subglobose, reddish-purple, 2-lobed, sparsely hairy [14].

Grewia tiliaefolia Vahl, belongs to the family tilaceae is generally found in the forest of Anangan mala, which is a part of Western Ghats, in the northern end of Palakkad district, Kerala, India. Grewia tiliaefolia contain chemicals like D-erythro-2-hexenoic acid $\gamma$ lactone, Gulonic acid $\gamma$ lactone, Betulin, Friedelin, Lupeol, Tannins, Flavonoids, Hemicelluloses, Phenolics, Lupenol, and Lignin [15-18].

Related studies done in various plants as a reference like Iqbal Ahamad et al. (2006) detected major groups of compounds as the most active fraction of four plants extracts by infrared spectroscopy [19]. Ramamoorthi and Kannan (2007) screened the bioactive group 
of chemicals in the dry leaf powder of Calotropis gigantea by FTIR analysis. Kareru et al. (2008) detected saponins in the crude dry powder of 11 plants using FTIR spectroscopy [20]. Analgesic and antipyretic activity of aqueous extract of Grewia tiliaefolia Vahl leaves were reported [21]. Antioxidant and antiproliferative activity of methanolic extract of Grewia tiliaefolia (Vahl) bark in different cancer cell lines [22]. The Fourier Transform Infrared (FTIR) spectroscopy allows the analysis of a relevant amount of compositional and structural information in plants. Moreover, FTIR spectroscopy is an established time-saving method to characterize and identified functional groups [23].

\section{MATERIALS AND METHODS}

\section{Collection, authentication and processing of plant material}

The plant material was collected in 2016 from kambalakonda forest area, Andhra Pradesh, India and authenticated by Dr. B. S. Padal, taxonomist, Department of Botany, Andhra University,
Visakhapatnam, Andhra Pradesh. The Voucher specimens A. U.(B. D. H),NO.22231 were deposited in the herbarium, A. U. College of Pharmaceutical Sciences, Andhra University.

The samples were washed thoroughly in running tap water to remove soil particles and adhered debris and finally washed with sterile distilled water. The leaves were cut, shade dried, ground into a fine powder and stored in airtight polythene bags until use.

\section{Extraction}

The shaded dried leafs were powdered in the medical grinder. 100 grams of leaf powder was weighed, $300 \mathrm{ml}$ of different solvents (hexane, petroleum ether, chloroform, ethyl acetate, methanol, acetone, benzene and distilled water) used each and individually with soxhlet extraction method for $72 \mathrm{~h}$. The extract was filtered using Whatman No.1 filter paper and the filtrate was collected (crude extracts). It was then transferred to glass vials and kept at $4{ }^{\circ} \mathrm{C}$ for future use.

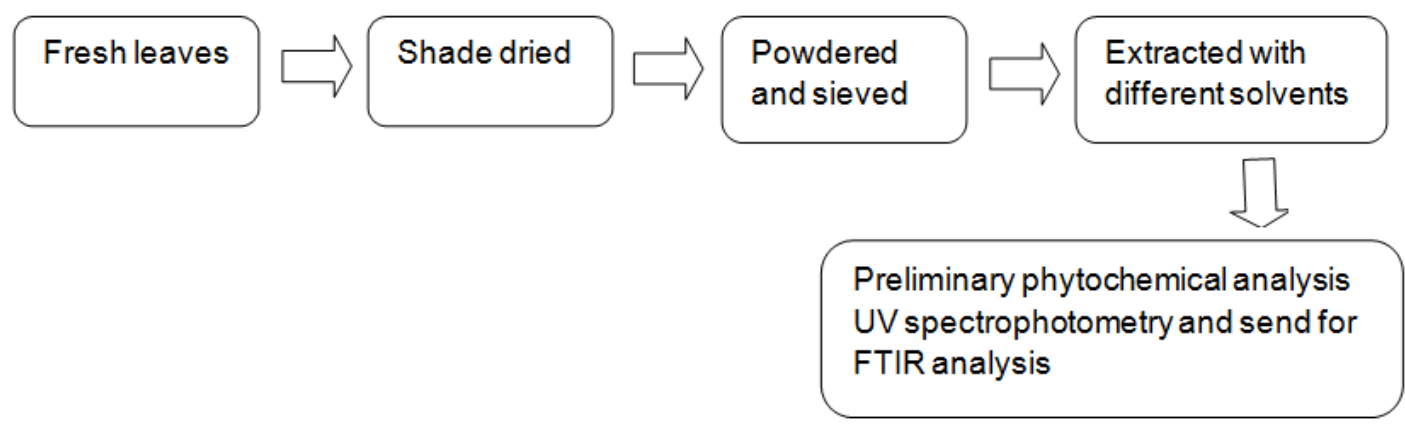

Fig. 1: Schematic representation of extraction processes

\section{Preliminary phytochemical analysis}

Qualitative phytochemical analysis was carried out [24-26] and the results observed were based on the colour change or precipitate formation after the addition of specific reagents.

\section{Fourier transform infrared spectrophotometer (FTIR)}

Fourier Transform Infrared Spectrophotometer (FTIR) is the most powerful tool for identifying the types of chemical bonds and functional groups present in compounds. The wavelength of light absorbed is characteristic of the chemical bond. By interpreting the infrared absorption spectrum, the chemical bonds in a molecule can be determined. Dried powder of different solvent extracts of each plant materials was used for FTIR analysis. $10 \mathrm{mg}$ of the dried extract powder was encapsulated in $100 \mathrm{mg}$ of $\mathrm{KBr}$ pellet, in order to prepare translucent sample discs. The powdered sample of each plant specimen was loaded in FTIR spectroscope (Shimadzu, IR Affinity 1, Japan), with a Scan range from 400 to $4000 \mathrm{~cm}^{-1}$ with a resolution of $4 \mathrm{~cm}^{-1}$.

\section{RESULTS}

Table 1: Preliminary phytochemical screening

\begin{tabular}{|c|c|c|c|c|c|}
\hline Phytochemicals & Hexane & Ethyl acetate & Methanol & Crude methanol & Crude aqueous extract \\
\hline Phytosterols & + & + & + & + & + \\
\hline Terpenoids & + & + & + & + & + \\
\hline Saponins & - & + & + & + & + \\
\hline Flavonoids & - & + & + & + & + \\
\hline Tannins & + & + & + & + & + \\
\hline Carbohydrates & - & - & - & - & - \\
\hline Alkalods & - & + & + & + & - \\
\hline Amino Acids & - & - & - & - & - \\
\hline Phenols & + & + & + & + & + \\
\hline Quinones & - & - & + & + & - \\
\hline Glycosides & - & & + & + & + \\
\hline Proteins & - & - & - & - & - \\
\hline
\end{tabular}

Successively extracted using Hexane; Ethylacetate; Methanol and Crude Methanol; Crude Aqueous extracts'+' indicates presence; '-' indicates an absence

\section{Functional groups identification}

The FTIR spectrum was used to identify the functional groups of the active components present in extract based on the peaks values in the region of IR radiation.
When the extract was passed into the FTIR, the functional groups of the components were separated based on the ratio of its peak. The results of FTIR analysis confirmed the presence of alcohol, phenol, alkanes, aldehyde, aromatic compound, secondary alcohol, aromatic amines, and halogen compound. 
Table 2: Hexane extracts FTIR interpretation of compounds

\begin{tabular}{llll}
\hline Extract & Wavenumber $\left(\mathbf{c m}^{-1}\right)$ & Functional group & Phytocompounds identified \\
\hline Hexane & 3741.33 & Non bonded,OHstretching & Hydroxy group \\
& 2922.81 & Symmetric stretching of $-\mathrm{CH}_{2}\left(\mathrm{CH}_{2}\right)$ vibration & Lipids,proteins \\
& 2855.21 & Symmetric stretching of $-\mathrm{CH}_{2}\left(\mathrm{CH}_{2}\right)$ vibration & Lipids,proteins \\
& 2376.61 & O-H stretching & Carboxilic acid \\
& 1734.32 & C=0 stretching & Aldehyde Compound \\
& 1551.25 & C=C stretching & \\
& 1456.92 & C=C-C Aromatic ring stretching & Aromatic Compound \\
& 1377.55 & O-H bening,alcoholic group & Phenol or tertiary alcohol \\
& 1247.13 & CN stretching & Aromatic primary amine \\
& 729.25 & C-Cl stretching & Aliphatic Chloro Compound \\
\hline
\end{tabular}

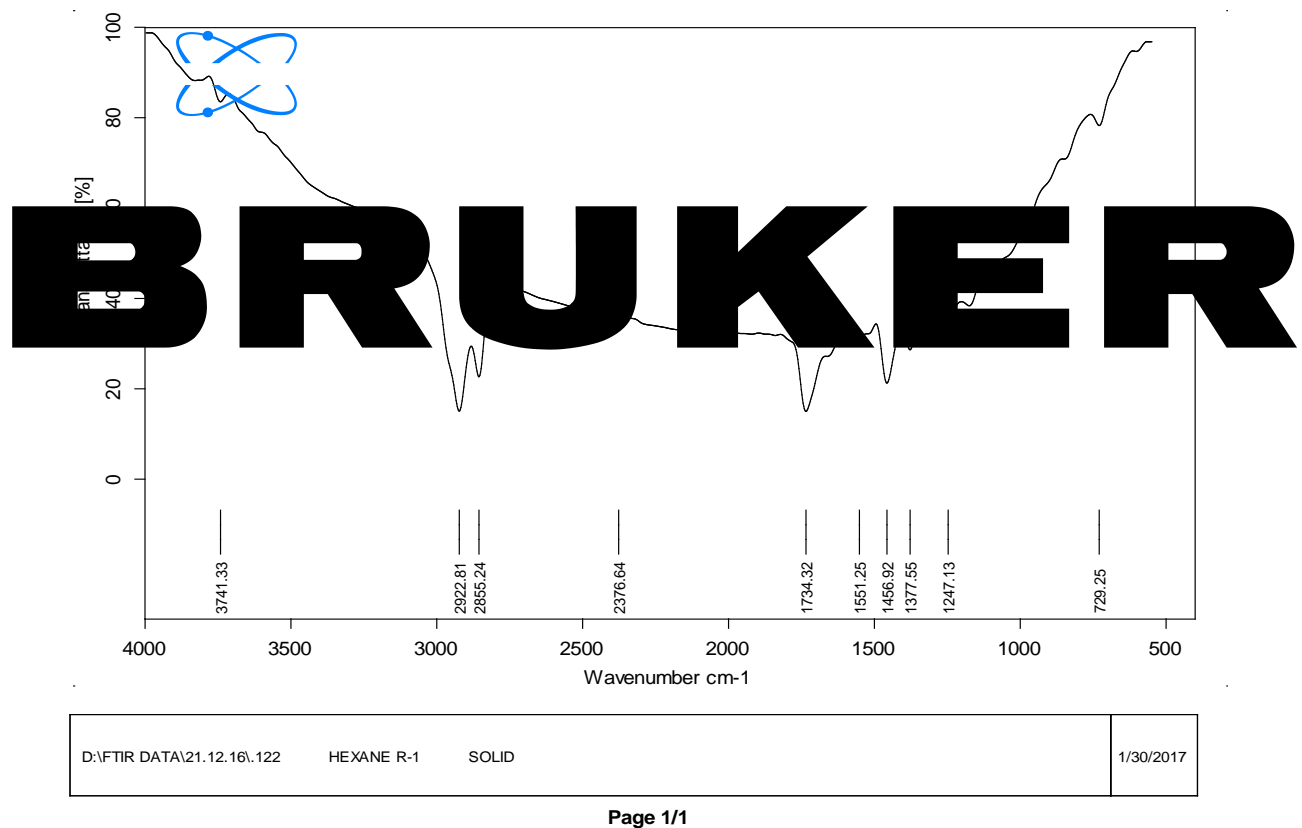

Fig. 1: FTIR spectrum of hexane extracts of Grewia tilifolia leaf

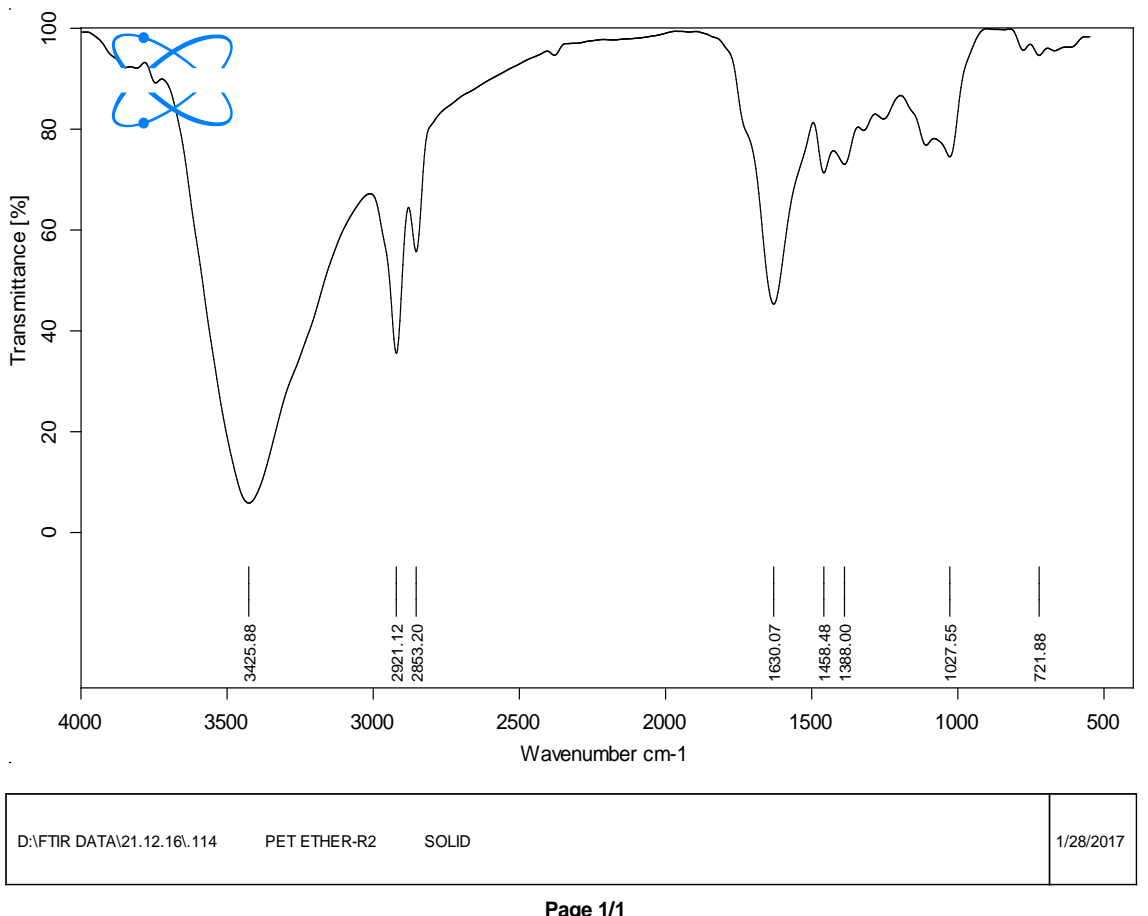

Fig. 2: FTIR spectrum of petroleum ether extracts of Grewia tilifolia leaf 
Table 3: Petrolium ether extract FTIR interpretation of compounds

\begin{tabular}{llll}
\hline Extract & Wavenumber $\mathbf{( \mathbf { c m } ^ { - 1 } )}$ & Functional group & Phytocompounds identified \\
\hline Petrolium Ether & 3425.88 & O-H stretching,H-bonded & Hydroxy Compound \\
& 2921.12 & Asymmetric stretching of- $\mathrm{CH}\left(\mathrm{CH}_{2}\right)$ vibration & Saturated aliphatic Compound-Lipids \\
2853.20 & Symmetric stretching of- $\mathrm{CH}_{2}\left(\mathrm{CH}_{2}\right)$ vibration & Lipids,proteins \\
1630.07 & C=O stretching & Ketone Compound \\
& 1458.48 & C=C-C Aromatic ring stretching & Aromatic Compound \\
& 1388.00 & O-H bening,alcoholic group & Phenol or tertiary alcohol \\
& 1027.55 & Phosphate ion & Phosphate Compound \\
& 721.88 & C-Cl stretching & Aliphatic Chloro Compound \\
\hline
\end{tabular}

Table 4: Chloroform extract FTIR interpretation of compounds

\begin{tabular}{llll}
\hline Extract & Wavenumber $\left(\mathbf{c m}^{-1}\right)$ & Functional group & Phytocompounds identified \\
\hline Chloroform & 3807.14 & Non bonded,Ohstretching & Hydroxy group \\
& 3760.15 & Non bonded,Ohstretching & Hydroxy group \\
& 3612.15 & Non bonded,Ohstretching & Hydroxy group \\
& 2975.32 & C-Hstretching & Lipids,proteins \\
& 2866.14 & Symmetric stretching of- $\mathrm{CH}_{2}\left(\mathrm{CH}_{2}\right)$ vibration & Carboxilic acids \\
& 2377.41 & O-H stretching,Acidic & Nitrile Compound \\
& 2275.21 & Multiple bonding & Carbonyl Compound \\
& 1705.07 & $\mathrm{C}=$ O stretching & Amide \\
& 1652.78 & $\mathrm{C}=$ Ostretching & Aromatic \\
& 1547.80 & $\mathrm{C}=\mathrm{C}$ stretching & Aromatic Compound \\
& 1462.07 & $\mathrm{C}=\mathrm{C}-\mathrm{C}$ Aromatic ring stretching & \\
\hline
\end{tabular}

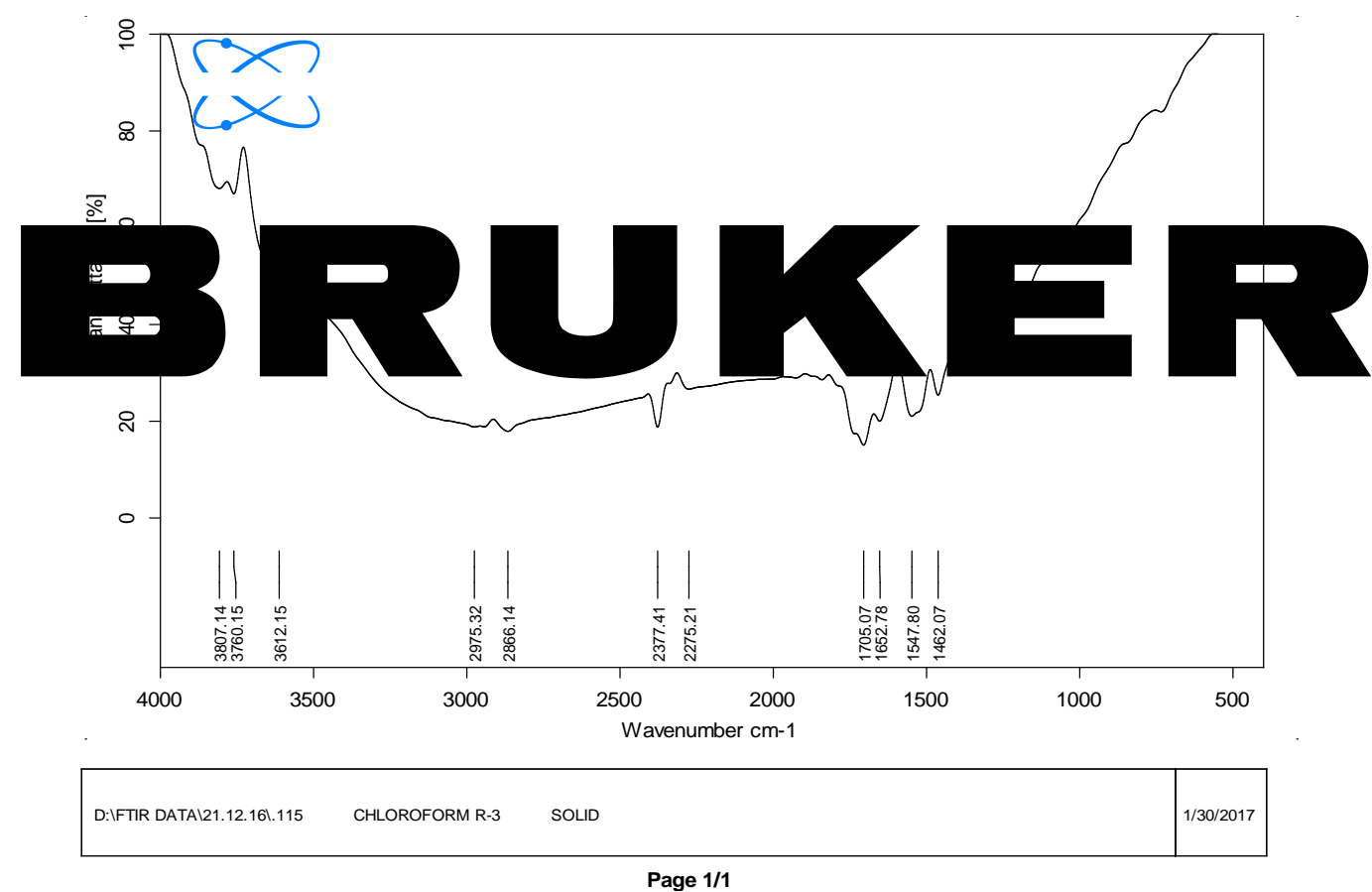

Fig. 3: FTIR spectrum of chloroform extract of Grewia tilifolia leaf

Table 5: Ethyl acetate extract FTIR interpretation of compounds

\begin{tabular}{|c|c|c|c|}
\hline Extract & Wavenumber $\left(\mathrm{cm}^{-1}\right)$ & Functional group & Phytocompounds identified \\
\hline \multirow[t]{6}{*}{ Ethyl Acetate } & 3391.83 & O-H stretching & Poly Hydroxy Compound \\
\hline & 2923.19 & Asymmetric stretching of- $\mathrm{CH}\left(\mathrm{CH}_{2}\right)$ vibration & Lipids,proteins \\
\hline & 2855.84 & Symmetric stretching of $-\mathrm{CH}_{2}\left(\mathrm{CH}_{2}\right)$ vibration & Lipids,proteins \\
\hline & 1728.50 & $\mathrm{C}=\mathrm{O}$ stretching & Carbonyl Compound \\
\hline & 1454.88 & $\mathrm{C}=\mathrm{C}-\mathrm{C}$ Aromatic ring stretching & Aromatic Compound \\
\hline & 1379.79 & $\mathrm{O}-\mathrm{H}$ bening,alcoholic group & Phenol or tertiary alcohol \\
\hline
\end{tabular}




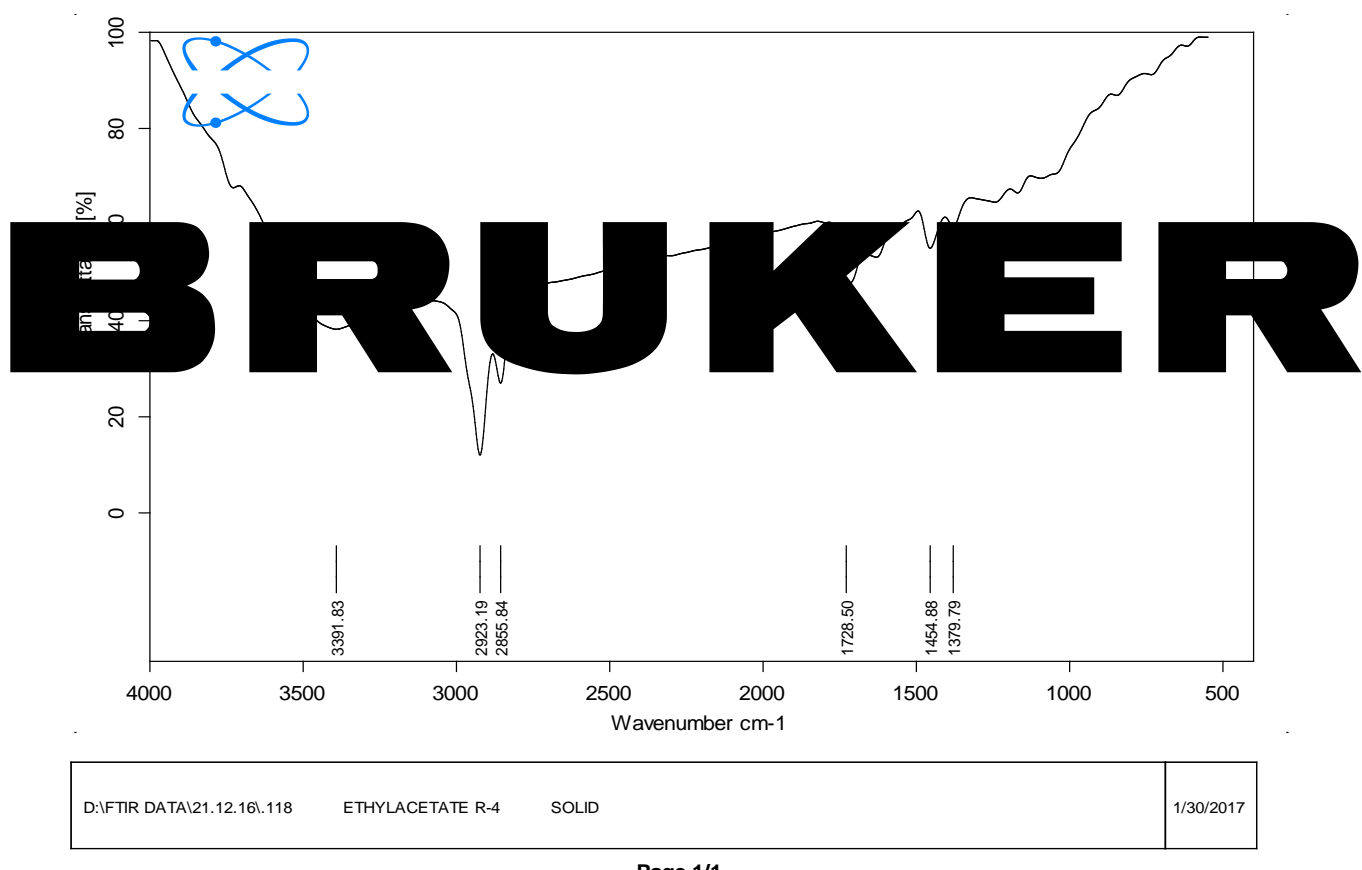

Fig. 4: FTIR spectrum of ethyl acetate extract of Grewia tilifolia leaf

Table 6: Acetone extract FTIR interpretation of compounds

\begin{tabular}{llll}
\hline Extract & Wavenumber $\left(\mathbf{c m}^{-1}\right)$ & Functional group & Phytocompounds identified \\
\hline Acetone & 3424.53 & O-H stretching,H-bonded & Hydroxy Compound \\
& 2925.38 & Symmetric stretching of- $\mathrm{CH}_{2}\left(\mathrm{CH}_{2}\right)$ vibration & Lipids,proteins \\
& 2856.55 & Symmetric stretching of- $\mathrm{CH}_{2}\left(\mathrm{CH}_{2}\right)$ vibration & Lipids,proteins \\
1732.03 & C=O stretching & aldehyde Compound \\
1628.03 & C=O stretching vibrations,ketone group & Ketone Compound \\
& 1453.46 & C=C-C Aromatic ring stretching & Aromatic Compound \\
& 1380.08 & O-H bening,alcoholic group & Phenol or tertiary alcohol \\
& 1241.35 & C-N stretching vibrations & Aromatic primary amine \\
& 1169.18 & & Cyclic ether \\
& 1084.27 & C-O stretching,Ether group & Aromatic Phosphate \\
& 838.69 & P-O-C stretching & Aliphatic Chloro Compound \\
& 724.73 & C-Cl stretching &
\end{tabular}

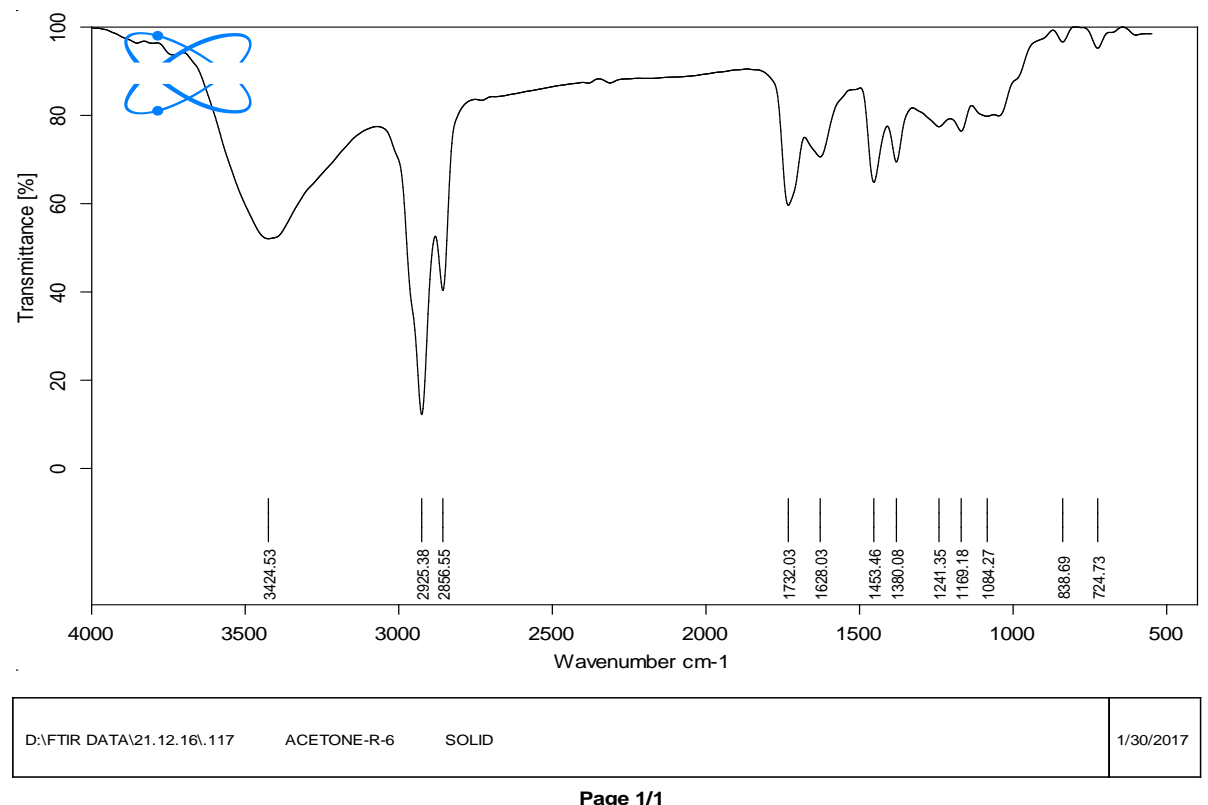

Fig. 5: FTIR spectrum of acetone extract of Grewia tilifolia leaf 
Table 7: Benzene extract FTIR interpretation of compounds

\begin{tabular}{|c|c|c|c|}
\hline Extract & Wavenumber $\left(\mathrm{cm}^{-1}\right)$ & Functional groups & Phytocompounds identified \\
\hline \multirow[t]{13}{*}{ Benzene } & 3832.23 & Non bonded,Ohstretching & Hydroxy group \\
\hline & 3742.13 & Non bonded,Ohstretching & Hydroxy group \\
\hline & 3612.67 & Non bonded,Ohstretching & Hydroxy group \\
\hline & 3565.07 & $\mathrm{O}-\mathrm{H}$ stretching,Hydroxy group (Intermolecular hydrogen-bonded $\mathrm{OH}$ ) & Poly Hydroxy Compound \\
\hline & 2377.67 & & \\
\hline & 2303.30 & $\mathrm{C}=\mathrm{C}$ stretching(chelating compounds) & \\
\hline & 1834.16 & Carbonyl Compound frequency & Transition metal carbonyls \\
\hline & 1742.02 & $\mathrm{C}=\mathrm{O}$ stretching & Ester \\
\hline & 1700.22 & $\mathrm{C}=\mathrm{O}$ stretching Carbonyl & Carbonyl Compound \\
\hline & 1652.52 & $\mathrm{C}=0$ stretching & Amide \\
\hline & 1543.27 & $\mathrm{C}=\mathrm{C}$ stretching & Aromatic \\
\hline & 1521.22 & $\mathrm{C}=\mathrm{C}$ stretching & Aromatic \\
\hline & 1470.45 & $\mathrm{C}=\mathrm{C}-\mathrm{C}$ Aromatic ring stretching & Aromatic Compound \\
\hline
\end{tabular}

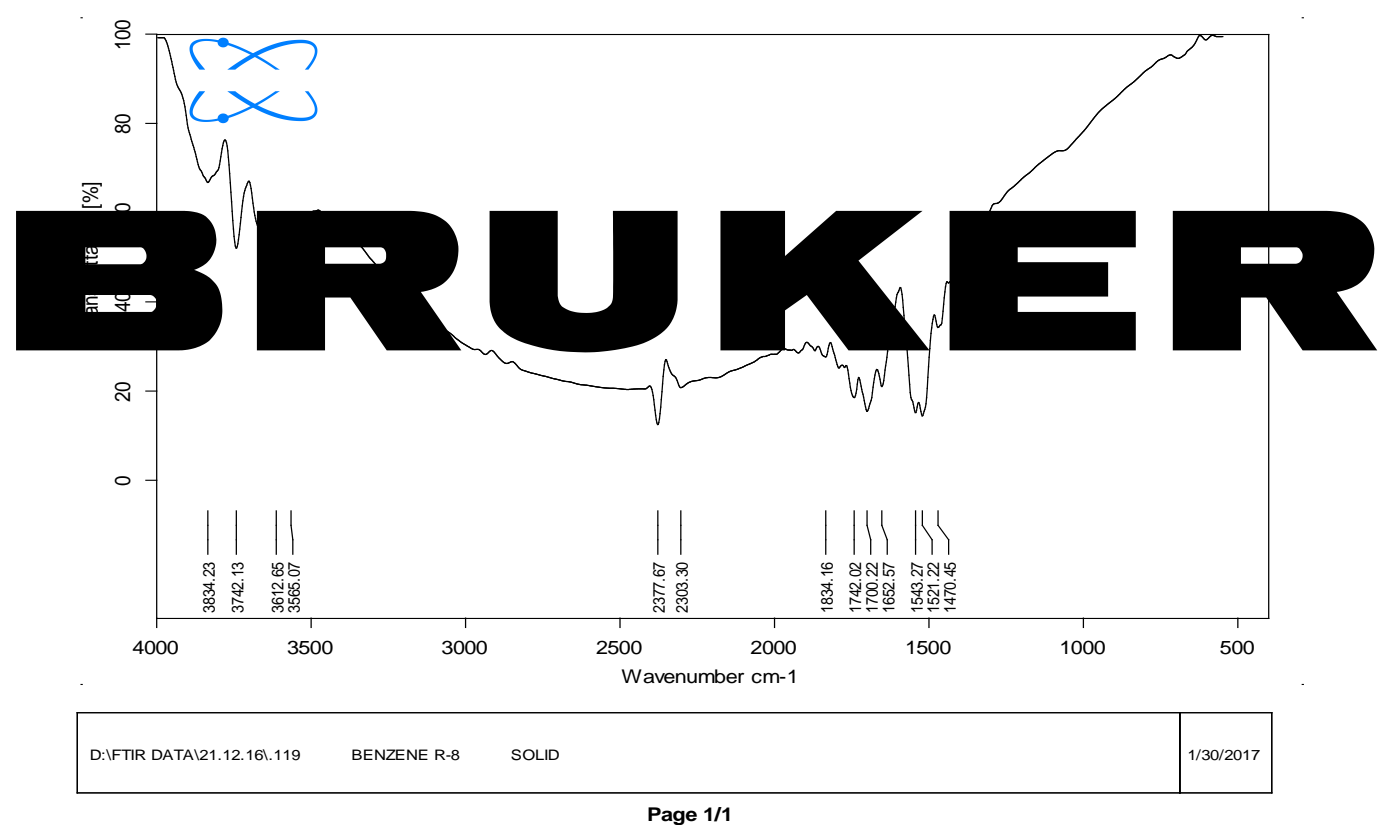

Fig. 6: FTIR spectrum of benzene extract of Grewia tilifolia leaf

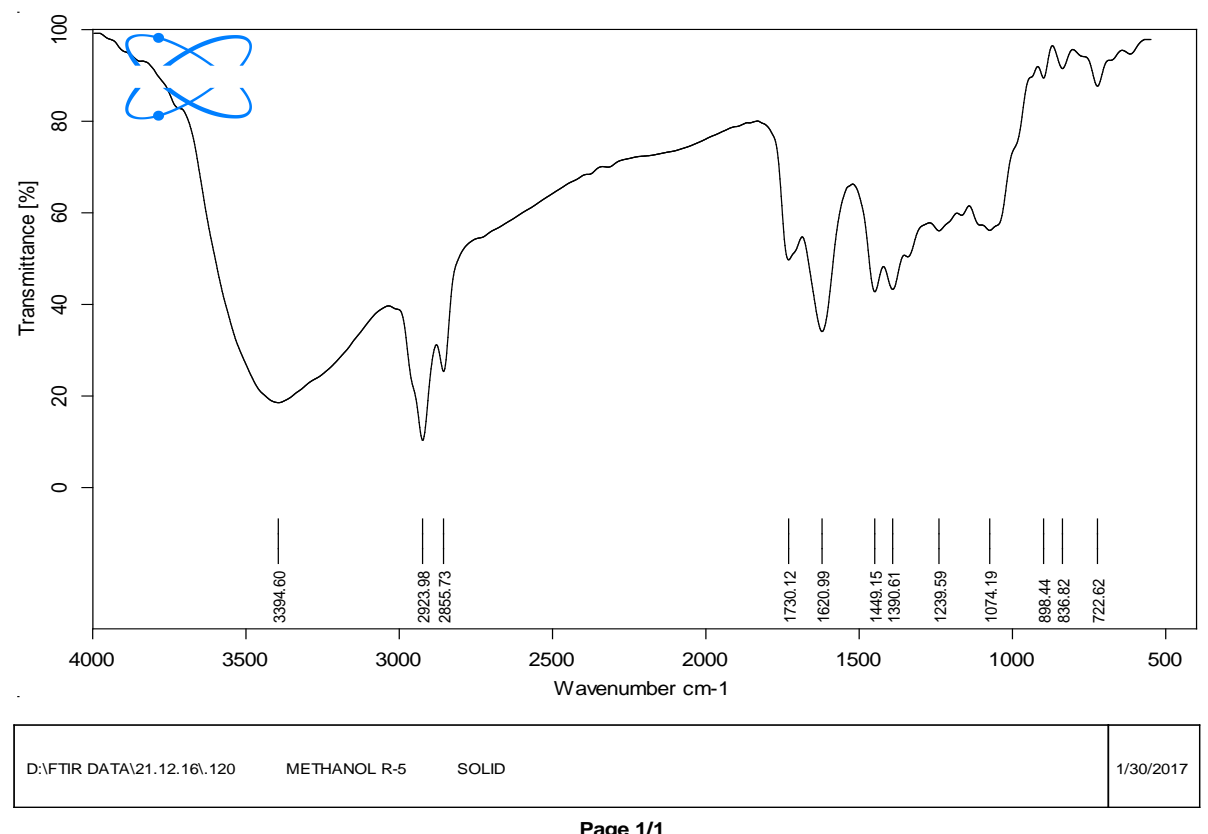

Fig. 7: FTIR spectrum of methanolic extract of Grewia tilifolia leaf 
Table 8: Methanolil extract FTIR interpretation of compounds

\begin{tabular}{llll}
\hline Extract & Wavenumber $\left(\mathbf{c m}^{-1}\right)$ & Functional Groups & Phytocompounds identified \\
\hline \multirow{3}{*}{ Methanol } & 3394.60 & O-H stretching H-bonded & Hydrogen Compounds \\
& 2923.98 & Asymmetric stretching of- $\mathrm{CH}\left(\mathrm{CH}_{2}\right)$ vibration & Saturated aliphatic Compound-Lipids \\
& 2855.73 & Symmetric stretching of- $\mathrm{CH}_{2}\left(\mathrm{CH}_{2}\right)$ vibration & Lipids,proteins \\
& 1730.12 & C=Ostretching & Aldehyde Compound \\
& 1620.99 & C=Ostretching & Ketone Compound \\
& 1449.15 & C=C-C Aromatic ring stretching & Aromatic Compound \\
& 1390.61 & O-H bending,Alcoholic group & Phenol or tertiary alcohol \\
& 1239.59 & CN stretching & Aromatic primary amine \\
& 1074.19 & Phasphate ion & Phasphate Compound \\
& 898.44 & P-O-C stretching & Aromatic phosphates \\
& 836.82 & P-O-C stretching & Aromatic phosphates \\
& 722.64 & C-Cl stretching & Aliphatic Chloro Compound \\
\hline
\end{tabular}

Table 9: Distilled water extract FTIR interpretation of compounds

\begin{tabular}{llll}
\hline Extract & Wavenumber $\left(\mathbf{c m}^{-1}\right)$ & Functional groups & Phytocompounds identified \\
\hline Aqueous & 3416.31 & N-H stretching & Amine \\
& 1627.24 & C=O stretchingvibration, ketone group & Ketone Compound \\
& 1404.14 & O-H bend Alcoholic group & Phenol or tertiary alcohol \\
& 1338.15 & CN stretching & Aromatic primary amine \\
& 1275.13 & CN stretching & Aromatic primary amine \\
& 1121.28 & C-O stretching, polymeric OH & Cycli ether \\
& 936.74 & P-O-C stretching & Aromatic phosphates \\
& 897.36 & P-O-C stretching & Aromatic phosphates \\
& 719.91 & C-Cl stretching & Aliphatic Chloro Compound \\
\hline
\end{tabular}

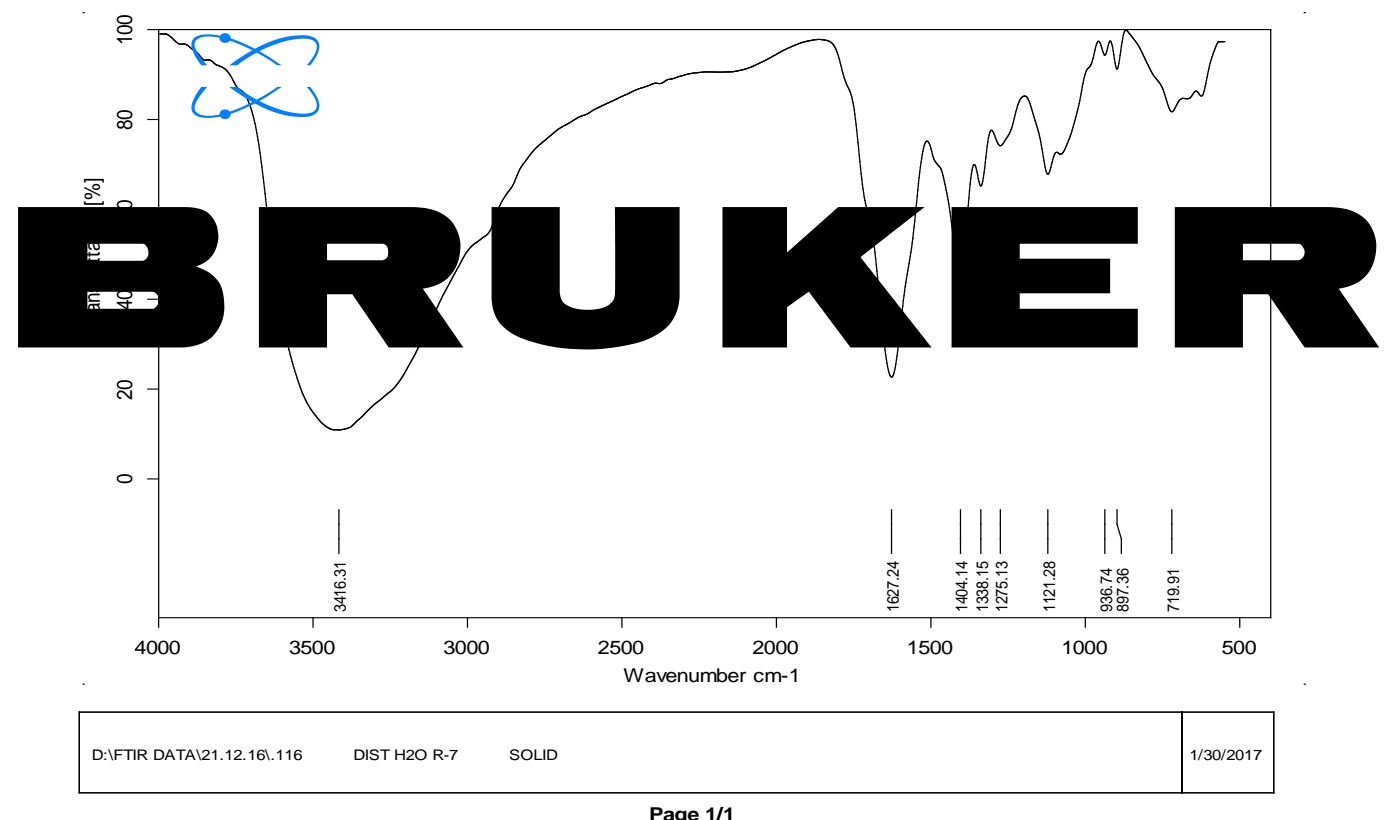

Fig. 8: FTIR spectrum of aqueous extract of Grewia tilifolia leaf

\section{DISCUSSION}

The pharmacological action of crude drugs and other therapeutic uses are due to their therapeutically active constituents such as tannins, flavonoids, alkaloids and several other aromatic compounds or secondary metabolites of plants which serve as defense mechanism against predation by many microorganisms, insects and herbivores. So, the preliminary phytochemical analysis revealed pronounced importance because the crude drugs possess varied composition of secondary metabolites $[27,28]$

The FTIR anaylsis revealved the prescence of alkaloids due to $\mathrm{N}-\mathrm{H}$ stretching, polyphenols and flavonoids due to $\mathrm{O}-\mathrm{H}$ stretching, terpens due to $\mathrm{C}-\mathrm{H}$ group [29]. The functional groups present in test plant are aldehydes, alkenes, amines, amides, alcohols, phenols, aromatics, carboxylic acids and anhydride, esters and lactones, ethers and organic halogen compounds. These were confirmed by FT-IR spectrophotometer study that predicted the presence of the groups: $\mathrm{O}-\mathrm{H}, \mathrm{N}-\mathrm{H}, \mathrm{C}-\mathrm{H}, \mathrm{CCl}, \mathrm{C}=\mathrm{C}$, nitrates and silicates stretching. The presence of characteristic functional groups of carboxylic acids, anhydrides, alcohols, phenols, amines, amides, esters, ethers, sulphur derivatives, glycosides, nitrates, nitriles, isonitriles, organic halogens and carbohydrate could be responsible for the various medicinal properties of Grewia tilifolia [29].

\section{CONCLUSION}

In the present study analysis of different extracts of Grewia tilifolia (vahl) leaf was done under FTIR will act as Pharmacognostic marker to distinguish the medicinally important Grewia species this 
spectrocopic techinque is relatively simple,cost effective and can be usefull to easily detect functional groups. The results of present study is a way to predict and compare the phytoconstituents present in this plant with other bioactive medicinally important plants. Further the bioactive compounds need to be isolated and the structure of the compounds can be determined by using advanced analytical techniques such as Mass and NMR Spectrophotometers.

\section{ACKNOWLEDGEMENT}

The authors are thankful to the Rajiv Gandhi National FellowshipUGC, New Delhi for financial support which enabled me to successfully complete the research and AU college pharmaceutical sciences for providing lab facility.

\section{AUTHORS CONTRIBUTIONS}

All the author have contributed equally

\section{CONFLICTS OF INTERESTS}

The authors have no conflict of interest

\section{REFERENCES}

1. Kuldip S Dogra, Sandeep Chauhan, Jeewan S Jalal. Assessment of Indian medicinal plants for the treatment of asthma. J Med Plants Res 2015;32:851-62.

2. R Ashok Kumar, M Ramaswamy. Phytochemical screening by FTIR spectroscopic analysis of leaf extracts of selected Indian medicinal plants. Int J Curr Microbiol Appl Sci 2014;3:395-406.

3. Visveshwari M, Subbaiyan B, Thangapandian V. Phytochemical analysis, antibacterial activity, FTIR and GCMS analysis of ceropegia juncea roxb. Int J Pharm Pharm Res 2017;9:914-20.

4. Hashimoto A, Kameoka T. Applications of infrared spectroscopy to biochemical, food, and agricultural processes. Appl Spectrosc Rev 2008;43:416-51.

5. Hussain K, Ismail Z, Sadikun A, Ibrahim P. Evaluation of metabolic changes in fruit of piper armentosum in various seasons by metabolomics using fourier transform infrared (FTIR) spectroscopy. Int J Pharm Clin Res 2009;1:68-71.

6. Srinivasan PA, Arokiaraj A, Vijayarajan D. Isolation, spectral and optical analysis of fistulic acid-a phytochemical constituent of cassia fistula linn. Indian J Sci Technol 2011;4:422-4.

7. Boydem MR. The NCI in vitro anticancer drug discovery screen. In: Teicher B. (Ed.). Anticancer drug development guide; preclinical screening, clinical trials and approval, Humana Press, Totowa; 1997. p. 30.

8. Brand WW, Cuvelier HE, Berset C. Use of the free radical method to evaluate antioxidant activity. Food Sci Technol 1995;82:25-30.

9. Cassady JM, Douros JD. Eds. Anticancer Agents Based on Natural Product Models. Academic Press, New York; 1980.

10. Anjaneyulu B, Baburao V, Ganguly AK, Govindachari TR, Joshi BS, Kamat VN, et al. Chemical investigation of some Indian plants. Indian J Chem 1965;3:237-8.

11. Badami $S$, Vijayan $\mathrm{P}$, Mathew $\mathrm{N}$, Chandrashekhar $\mathrm{R}$, Godavarathi A, Dhanarajan SA, et al. In vitro cytotoxic properties of grewia tiliaefolia bark and lupeol. Indian J Pharmacol 2003;35:205-51.
12. Dhavan BN, Patnaik GK, Rastogi RP, Singh KK, Tandon JS. Screening of Indian plants for biological activity. Indian J Expt Biol 1977;15:208-19.

13. Chiruvella KK, Raghavan SC. A natural compound, methyl angolensate, induces mitochondrial pathway of apoptosis in Daudi cells. Invest New Drugs 2011;29:583-92.

14. N Sasidharan, BP Pal. Kerala Forest Research Institute, Peechi. Available from: https://indiabiodiversity.org/species/show/31410. [Last accessed on 10 Mar 2019]

15. Goyal PK. Phytochemical and pharmacological properties of the genus Grewia: a review. Int J Pharm Pharm Sci 2012;4:72-8.

16. Badami S, Vijayan P, Mathew N, Chandrashekhar R, Godavarthi A, Dhanaraj SA, et al. In vitro cytotoxic properties of grewia tiliaefoliabark and lupeol. Indian J Pharm 2003;35:250-1.

17. Anjaneyulu B, Baburao V, Ganguly AK, Govindachari TR, Joshi BS, Kamat VN, et al. Chemical investigation of some Indian plants. Indian J Chem 1965;3:237-8.

18. Badami S, Gupta MK, Ramaswami S, Rai SR, Najanan M, Bendell $\mathrm{DJ}$, et al. Determination of betulin in grewia tiliaefolia by HPTLC. J Sep Sci 2004;27:129.

19. Iqbal Ahmad, Farrukh Aqil. In vitro efficacy of bioactive extracts of 15 medicinal plants against EsbLproducing multidrugresistant enteric bacteria. Microbiol Res 2007;162:264-75.

20. Kareru PG, Keriko Gachanja JM, Kenji AN. Direct detection of triterpenoid saponins in medicinal plants. Afr J Tradit Complementary Altern Med 2008;5:56-60.

21. Sachin Shridhar Sakat, Archana Ramesh Juvekar. Analgesic and antipyretic activity of aqueous extract of grewia tiliaefolia Vahl leaves. J Pharm Res 2009;2:1475-8.

22. Selvam N Thamizh, Vengatakrishnan V. Evaluation of tissue level antioxidant activity of premna serratifolia leaf in paracetamol intoxicated wistar albino rats. Int J Pharm Life Sci 2010;1:86-90.

23. Grube M, Muter O, Strikauska S, Gavare M, Limane B. Application of FTIR spectroscopy for control of the medium composition during the biodegradation of nitro aromatic compounds. J Indian Microbiol Biotechnol 2008;35:1545-9.

24. Harborne JB. Methods of plants analysis: In: phytochemical methods. $2^{\text {nd }}$ Eds. UK: Chapman and hall; 1984.

25. Trease GE, Evans WC. Introduction and general methods in pharmacognosy. $13^{\text {th }}$ Eds. K: Cambridge University Press; 1989.

26. Raaman N. Phytochemical techniques, New India publishing agency, New Delhi; 2006.

27. Maria Lysete, Bastos A, Maria Raquel, Lima F, Lucia M, Conserva. Studies on the antimicrobial activity and brine shrimp toxicity of Zeyheria tuberculosa (Vell.) Bur. (Bignoniaceae) extracts and their main constituents. Ann Clin Microb Antimic 2009;8:16.

28. Meyer JJM, Afolayan AJ, Taylor MB, Erasmus D. Antiviral activity of galangin isolated from the aerial parts of Helichrysum aureonitens. J Ethnopharmacol 1997;56:165-9.

29. Maobe MAG, Nyarango RM. Fourier transformer infra red spectrophotometer analysis of warburgia ugandensis medicinal herb used for the treatment of diabetes, malaria and pneumonia in kisii region, southwest kenya. Global J Pharmacol 2013;7:61-8. 